\title{
THE SEARCH FOR LOCAL GOVERNMENT AUTONOMY IN NIGERIA: LEGAL AND INSTITUTIONAL PATHWAYS TO ITS REALIZATION
}

\author{
Ifeolu J. Koni*
}

\begin{abstract}
This article examines the status of the local government under the tripartite governmental system in Nigeria that has been in operation since 1979. It reviews the various reforms that the administration of local government has gone through from the colonial era till 1999 when the extant Constitution of Nigeria came into force. The article finds that notwithstanding the provision of section 7 of the 1999 Constitution which provides for a system of local government by democratic means, many of the State Governments have continued to set up caretaker committees at this tier of government, thereby denying the grassroots population of the benefits of democratic rule. The creation of the infamous State Joint Local Government Account has rendered the Local Governments totally prostrate as they depend completely on the State Governments for funds needed for their development. The article recommends, inter alia, that section 165 of the 1999 Constitution should be amended with a view to abolishing the State Joint Local Government Account and making the Local Government Councils both politically and financially autonomous.
\end{abstract}

Keywords: Search, local government, autonomy, pathways and realization

DOI: http://dx.doi.org/10.4314/jsdlp.v7i2.8

\section{INTRODUCTION}

A seasoned journalist and public affairs analyst, Eric Teniola, in The Punch Newspaper of 5 April 2016, appraised the status of the local government administration in Nigeria and concluded that the

* LL.B (Hons), Ilorin, LL.M, PhD (Ife) BL, Barrister and Solicitor of the Supreme Court of Nigeria; Senior Lecturer, College of Law, Afe Babalola University AdoEkiti, Nigeria. Email: ife4law@yahoo.com 
Constitution of the Federal Republic of Nigeria, 1999 (as amended) ${ }^{1}$ has been unfair to the local governments in the country. ${ }^{2}$ In the essay under reference, he wondered why none of the local governments in the federation was able to implement any capital project ${ }^{3}$ in the various communities in which they are domiciled even though none of them received anything less than N60m in January 2016 despite the dwindling revenue of the country.

The point Teniola raised in his column is one that has been agitating the minds of concerned Nigerians over the years. Notice that under the tripartite governmental arrangement being practised in Nigeria, the Local Government is the third tier of government and the closest one to the people. Because of this closeness to the grassroots population, the Local Government is expected to make the most profound impact on the people, particularly the rural dwellers. It is for this reason that successive administrations at the centre have continued to focus attention on this tier of government. The Local Governments are designed to serve as an effective vehicle for the delivery of the muchneeded dividends of democracy. When they become ineffective, the rural communities are unable to feel the impact of government. This leads to mass discontent and disillusionment. This has been the story of the large majority of rural dwellers in Nigeria since the advent of democratic rule.

The continuous agitation for local government reform in Nigeria shows that all is not well with this tier of government. It is equally interesting that since 1976, successive regimes have been responding one way or the other to the calls for reform. Yet, the situation remains unchanged; the Local Councils have remained largely a lame duck. Consequently, the search for local government autonomy, which began more than 40 years ago still continues till date. Many analysts agree

1 The 1999 Constitution of Nigeria is referred to subsequently in this paper as 'the Constitution or 'the 1999 Constriction'.

2 Eric Teniola, 'Making Local Governments More Effective' Punch Newspaper (Lagos, 15 April 2016) 23.

3 He anchored his review on the total sum of N85.4bn shared by the 774 Local Government Areas from the federation account in January 2016. According to the breakdown, Lagos State got the highest with N5.4 billion followed by Kano State with N4.7 billion while Bayelsa State (with just eight local governments) had the least with N972 million. Obio/Akpor Local Government Area of Rivers State had the largest share with N156.6 million while none of the Local Governments in the Federation received any amount less than N60 million. 
on the need for a reform but there appears to be some divergence on the exact shape the reform should take. This article examines the legal and institutional frameworks for a comprehensive reform of this tier of government and how this can be achieved. Beginning with the evolution of the system of local government, the article appraises the various reforms that the administration of this tier of government has gone through in Nigeria, with particular emphasis on the Dasuki Report of 1976 in which the idea of a full-fledged autonomy being granted to the Local Government was first mooted. It also proposes a four-point agenda for the reform of the system of local government administration in Nigeria.

\section{EVOLUTION OF LOCAL GOVERNMENT ADMINISTRATION IN NIGERIA}

The administration of Local Government in Nigeria is by no means a new experience. The system evolved in the pre-colonial period and has changed its mode from one government to another to meet the peculiar needs of each era. Prior to the advent of colonialism, the traditional rulers and chiefs had been in charge of local administration in different parts of the country. In the South West, for instance, the Yoruba Obas took charge of communal affairs while in Northern Nigeria, the Emirs were in control. In the Eastern part of the country, the administration of local affairs was a bit complex, as the Obis could not wield much power due to the absence of a well-defined traditional institution.

Upon arrival, the British authority quickly established the Native Authority system, which formed the bedrock of the operation of the indirect rule system. This system, as rightly noted by Williams, favoured the British government since it was cost effective and less susceptible to resistance. ${ }^{4}$ The indirect rule system was the ruling of the people through their recognized traditional rulers who were already in place. Adewumi says, 'the golden age of Local Government had begun in Nigeria with the introduction of indirect rule system by Lord Lugard'. ${ }^{5}$

4 A. Williams, 'Evolution of Local Government Administration in Nigeria' The Guardian Newspaper (Lagos, 22 June 2003)14.

5 A. S. Adewumi, 'Creation of Local Government under the Civilian and Military Regimes' (Unpublished LL. B Long Essay, submitted to the Faculty of Law, University of Ilorin, Nigeria, November, 2001) 8. 
The traditional rulers who served as intermediaries between the local people and the colonial masters were charged with the duty of collecting taxes under the supervision of the colonialists. The traditional rulers performed quasi-legislative functions by making laws for the good governance of their domain; executive functions by maintaining laws and orders; and judicial functions by adjudicating over civil and criminal matters.

To facilitate the performance of these functions, the colonial authorities made ordinances to guide the activities of the Native Authorities. ${ }^{6}$ The Native Authority was made an instrument of the ruler who was assisted by Native Council of Traditional Rulers in an advisory capacity. As noted earlier, the pre-colonial States did not all have traditional institutions upon which Native Authorities could succeed on the same scale. To solve this problem, the Native Authority Ordinance made the traditional ruler the sole guardian of his domain such that where there were no natural rulers, quasi-monarchs were appointed to facilitate the indirect rule system.

Notably, that the official declaration of Nigeria as a Federation in 1954 paved the way for the system of local government to receive statutory recognition by the enactment of the Native Authority Law of 1954. In 1956, the powers of the native authorities were slightly modified with the reorganization of the native courts. From this point, the Local Government remained a strong unit of administration.

Between 1954 and 1967, the administration of local government experienced phenomenal reforms. The reforms took place differently across colonial Nigeria, depending on the readiness of each region. After the Second World War (WWII), nationalist demands had compelled the colonial authorities to introduce reforms even as the need to make Native Authorities an instrument of social development became more compelling. It was, in fact, the labour movement of British that saw the need to introduce democratic reforms in its African countries. The principle of election was thus introduced while a certain percentage of Native Authority Council membership was allocated to elected or selected representatives of the local community for the first time.

6 There were, for instance, the Native Authority Ordinance, the Native Revenue Ordinance and the Native Courts Ordinance. 
With the introduction of the principle of election, a more efficient administrative system came into being in the sense that the educated and politically conscious people became more active, leaving the traditional rulers to function in the background. The Native Authority Law empowered native authorities to exercise legislative ${ }^{7}$ executive $^{8}$ and judiciary powers. ${ }^{9}$ The native authorities could also set up Native Authority Police Force and Native Authority Prison Yard, pursuant to sections 21 and 36 of the Law, respectively. The Law also conferred on the native authorities the power to exercise control over the institutions mentioned above, in terms of the appointment and removal of their staff personnel. ${ }^{10}$

This was the situation until 1967 when the military government of General Yakubu Gowon made some reforms in the administration of Local Government. The main feature of this reform was the replacement of the term 'Native Authority' with that of 'Local Government', based on the recommendation of an advisory committee set up by the government. The committee had also recommended, inter alia, the splitting and the regrouping of the former native authorities and the appointment of Resident Administrators. The 1967 reform further pushed the traditional authorities away from the administration of Local Government in Nigeria.

It is noteworthy that the system of Local Government in Nigeria experienced a lull in the 13 years of military dictatorship, lasting between 1967 and 1979. The reason was that the military regime operated at best a two-tier system of governance. This notwithstanding, the issue of Local Government administration was put in the national agenda again in 1976 when the Murtala/Obasanjo regime prepared to return the country to civil rule. After wide consultations, there was unanimity of opinion that the basis for a return to democracy was the reform of Local Government. This led to the setting up of the Dasuki Committee the objective of which was to free the Local Government from excessive interference from other tiers of government.

The Dasuki Committee made far-reaching recommendations, which bordered on the devolution of statutory powers to the Local

$7 \quad$ Native Authority Law 1954, ss 38 and 44.

8 ibid ss 30-32.

9 ibid ss 13 and 16(1).

10 Pursuant to Native Authority Law 1954, ss 127 and 141. 
Government. The report of the committee formed the bedrock of the 1976 Local Government Reform, the main feature of which was the legal recognition of the Local Government as the third tier of government in Nigeria. This new status was reflected in the 1979 Constitution, which expressly provided for a system of Local Government by democratically elected Local Government Councils in Nigeria. ${ }^{11}$

Unfortunately, however, when the Second Republic collapsed in 1983, the system of Local Government by democratically elected Local Government Councils also collapsed with it. What happened between 1983 and 1999 was a system of administration in which the military government operated whimsically. Local Government Councils were created without recourse to the need for economic planning and development just as the Councils became avenues for people to withdraw funds from the federal purse.

The return of Nigeria to civil rule on 29 May 1999 brought about a re-birth of the Local Government. Its status as the third tier of government was restored in the new Constitution, which came into force on 5 May 1999, pursuant to Decree No 24 of 1999. ${ }^{12}$ In short, the 1979, 1989, and 1999 Constitutions of Nigeria declare in unison 'the system of Local Government by democratically elected Local Government Councils is by this Constitution guaranteed'.

\section{LOCAL GOVERNMENT REFORMS}

Local Government administration in Nigeria has experienced continuous reforms since 1954 when this tier of government received statutory approval by virtue of the Native Law Ordinance of that year. We shall now highlight the major features of the reform agenda, as pursued from 1967 to date.

\section{The 1967 Local Government Reform}

The 1967 reform had arisen from the need to effect boundary adjustments as a result of the creation of new states ${ }^{13}$ by the then Head

11 Constitution of the Federal Republic of Nigeria 1979, s 7(1).

12 Constitution of the Federal Republic of Nigeria (Promulgation) Decree, 1999.

13 The new states were: North Western, Kano, North Central, Benue-Plateau, Central West, North East, Western, Mid-Western, Kwara, Lagos, East Central and South Eastern States. 
of State, Gen. Yakubu Gowon (rtd). The military government set up an Advisory Committee to look into the boundaries of the existing Native Authorities and to advise on the devolution of power from the provincial system of administration. The committee recommended the replacement of the term 'Native Authority' with that of 'Local Government', and the splitting and regrouping of former Native Authorities. As part of the reform, Resident Administrators were appointed for each Local Government.

One major effect of the 1967 reform was that it substantially whittled down the influence and power of traditional rulers who hitherto had operated as local overlords. As noted by Ojo, ${ }^{14}$ the full impact of the 1967 reform could not take effect due to the impact of the civil war, which broke out that year. Thus, when the late Gen. Murtala Mohammed and his men struck in 1975, one of their priorities was the reform of the system of Local Government in Nigeria.

\section{Local Government Reform}

The basic idea behind the 1976 reform was the need to democratize administration at the grassroots. The Murtala/Obasanjo administration had thought of the best approach to return the country to civil rule. This led to consultations with different interest groups at the end of which it was unanimously agreed that the basis for a smooth return to democratic rule was the reform of the administration of Local Government. This led the regime to set up a technical committee, popularly known as the 'Dasuki Committee' to look into how best the proposed reform could be carried out.

Described as a watershed in the history of the local government system in Nigeria, ${ }^{15}$ the Report of the Dasuki Committee marked a conscious attempt to visualize the structure and functions of Local Government. The committee recommended that the following functions, among others, should be given priority by the Local Government:

a. Basic environmental sanitation and other aspects of preventive health care;

14 A. O. Ojo, Political Science and Government of Nigeria (Ilesanmi Press Ltd, Ibadan, 1973) 255.

15 S. S. Ameh (SAN), 'The Local Government system under the 1999 Constitution'(2003) 1(1) Nigerian Bar Journal, 23. 
b. Maternity centres, dispensaries, leprosy clinics and health centres;

c. Roads and drain[age]s, excluding federal and State roads;

d. Construction and maintenance of primary schools; and

e. Maintenance of law and order.

The committee also identified the primary responsibilities of Local Government to include the following:

a. Making appropriate services and development activities responsive to local wishes and initiatives by devolving or delegating them to local representative bodies;

b. Facilitating the exercise of democratic self-government close to the local level of our society and encouraging initiatives and leadership potentials; and

c. Mobilizing human and material resources through the involvement of members of the public in their local development. One of the striking recommendations of the Committee was that the independent existence of the system of Local Government should be guaranteed by the Constitution.

Government accepted these recommendations and anchored the 1976 reform substantially on them. Accordingly, the establishment, structure, composition, finance and functions of the Local Government Councils were embodied in the 1979 Constitution. ${ }^{16}$

\section{The Post-1976 Reform Agenda}

As comprehensive as the 1976 reform was, and despite its being made a constitutional matter for the very first time, it did not put at rest the agitation for a review of the status of local government administration in Nigeria. Since 1976, and as correctly pointed out by Teniola, ${ }^{17}$ the central government has been most concerned about the fate of Local Government in Nigeria.

Upon the return of the military to power in 1984, the then Head of state, Gen. Muhammadu Buhari, set up another committee on Local Government, headed by the same Ibrahim Dasuki. The panel

16 Constitution of the Federal Republic of Nigeria 1979, s 7(1).

17 Eric Teniola (n 2). 
recommended, inter alia, that the 'single-tier' multi-purpose system of Local Government should be upheld, while noting that the problems militating against the reform were more operational than structural. The military government through a White Paper issued in 1985 accepted the report of the committee. Unfortunately, the White Paper could not be implemented before the Buhari/Idiagbon regime was overthrown in a palace coup on 27 August 1985.

In January 1986, there was another attempt to reform the administration of Local Government in Nigeria. The new military government, headed by Gen. Ibrahim Babangida, inaugurated a Political Bureau to conduct a debate on the political future of Nigeria. The Bureau discussed many issues bordering on the 'National Question', including the future of the local government system. The Bureau's discussion of Local Governments came under the sub-title 'Local Government for Development. ${ }^{18}$ The Bureau's Report, by and large, adopted the recommendations of the Dasuki Committee while emphasizing the political nature of Local Governments.

A major highlight of the recommendations of the Bureau was the abrogation of the title of 'Sole Administrator' and its replacement with the 'Chairmanship' and 'Councillorship' system. Thus, for the first time, an Executive Chairman was put in charge of the Local Government Council. The report stipulated fiscal structure, internal audit system and created a Directorate of Local Government in each State. One major feature of this reform was that the federal revenue allocated to Councils, which used to come through the States was now to be disbursed directly to the Councils. Furthermore, the presidential system of government was introduced to the Councils, providing both executive and legislative arms at this tier of government. It is noteworthy that the favourable disposition, which the Babangida regime had towards the local government administration, was reflected in the elaborate provisions for a Local Government system in the abortive 1989 Constitution.

Mention must also be made of an abortive attempt by the late Gen. Sani Abacha to reform the Local Government system in 1994. The failed reform was part of the agenda of the Constitutional Conference; tagged 'Agenda 94' set up to design a new Constitution for Nigeria. The regime was yet to consider the report of the conference when Gen. Abacha died in 1998. However, the Abacha regime had in

18 See S.S. Ameh (n15) 23. 
1997 promulgated a Decree, empowering the Head of State to dissolve any Council whose activities are not being managed in the best interest of the community. This, perhaps, was a foretaste of what might have been the focus of the abortive reform.

On the assumption of office in 1999, Chief Olusegun Obasanjo set up a committee on the review of the 1999 Constitution. The recommendations of the committee on the Local Government, were:

(a) Section 7(1) and (2) of the Constitution to be retained so that State Houses of Assembly have power to legislate on the creation and other necessary powers of the Local Government Councils in the spirit of true federalism.

(b) Section 7 is expanded to take care of the provisions made in this review to issue the existence and proper function of Local Government Councils.

(c) In line with the call for the security of tenure for elected Local Government functionaries, a new provision for qualifications and removal of the Chairman, Vice-Chairman and Councillors has been recommended as a separate tier of government within the States.

(d) In order to strike a balance between the demand by the Local Governments for financial autonomy through direct funding from the Federation Account and the need to ensure financial probity on the part of the Local Governments and the State Governments, it is recommended that section 162 (5) be amended so that all disbursements to the Local Government go to the State Local Government Joint Account as provided in section 162 (6). ${ }^{19}$

Former President Obasanjo was apparently not satisfied with the report of this panel, which was headed by Chief Clement Ebri, former Governor of Cross River State. He, therefore, set up another panel in 2003 to review the local government system. Headed by the then Etsu NUPE, Alhaji Umaru Ndayako, the committee was charged with the responsibility of, inter alia, examining the problem of inefficiency and the high cost of governance with a view to reducing costs and wastages at the three tiers of government and reviewing the performance of Local Governments within the last four years. The committee was also

19 Eric Teniola, op. cit (note 2). 
to consider the desirability or otherwise of retaining the Local Governments in the next constitutional dispensation. Another term of reference was to consider a modified version of the pre-1976 local system of government in Nigeria. The Committee submitted its report four months after it was inaugurated. A major feature of the report was the issue of direct funding of Local Governments, which had featured prominently in the recommendations of other panels before it.

The use to which Chief Obasanjo put the report of the Ndayako panel is not very clear. What is obvious is that the structure of the local government administration as contained in the 1999 Constitution is as it was under the 1979 Constitution. This means that the far-reaching reforms suggested in 1984 up to 2003 are yet to be reflected in the extant Constitution of Nigeria. The reason for this, of course, could be that none of the efforts aimed at a substantial review of the Constitution yielded any fruitful dividend during the period. An opportunity to achieve a comprehensive review of the Constitution in a manner that would have accommodated the reform of Local Government, it will be recalled, was lost in 2007 due to the smuggling of Chief Obasanjo's alleged third term agenda into the report of the Ibrahim Mantu-led Constitution Review Committee. The Senate rejected the Committee's report in the heat of the passion and controversy generated by the rumoured third term agenda.

\section{REVISITING THE QUESTION OF LOCAL GOVERNMENT AUTONOMY}

The first time the autonomy being granted to the administration of Local Government in Nigeria would be addressed was in 1976. The Dasuki Committee had identified one of the primary responsibilities of the Local Government as 'the exercise of democratic self-government close to the local level of our society...'. In accepting the recommendations of the panel, the then military government had approved the establishment, structure, composition, finance and functions of the Local Government Council as a separate tier of government. This was reflected in section 7 (1) of the 1979 Constitution. The same provision is embodied in section 7 (1) of the 1999 Constitution. ${ }^{20}$ The latter, for ease of reference, is reproduced here:

20 The latter, for ease of reference, is reproduced here:

7 (1) The system of local government by democratically elected local government 
The provisions of section 7 (1) of the 1999 Constitution are, no doubt, a response to the recommendations of the Dasuki Committee. A strict construction of the section, particularly subsection (1) thereof, reveals a clear intention of the Legislature to create the Local Government Council as a separate and distinct tier of government in Nigeria. It is also clear from the provision that the State Governments are under a constitutional obligation to ensure the existence of these councils through democratic means. The emphasis on 'the system of local government by democratically elected local government council...' is quite instructive. Under the Constitution, there is no provision for 'caretaker committees' now in vogue in many of the States of the Federation. It is submitted that the State Governors who have set up caretaker committees in the Local Government Councils of their respective States are committing gross illegality for which they ought to be sanctioned. It is scandalous that some of these caretaker committees have been in the saddle for a period that is even longer

councils is under this Constitution guaranteed; and accordingly, the Government of every State shall, subject to section 8 of this Constitution, ensure their existence under a Law which provides for the establishment, structure, composition, finance and functions of such councils.

(2) The person authorized by law to prescribe the area over which a local government council may exercise authority shall-

(a) Define such area as clearly as practicable; and

(b) Ensure, to the extent to which it may be reasonably justifiable, that in defining such area, regard is paid to-

(i) The common interest of the community in the area;

(ii) The traditional association of the community; and

(iii) Administrative convenience

(3) It shall be the duty of a local government council within the State to participate in economic planning and development of the area referred to in subsection (2) of this section and to this end an economic planning board shall be established by a Law enacted by the House of Assembly of the State.

(4) The Government of a State shall ensure that every person who is entitled to vote and be voted for at an election to a House of Assembly shall have the right to vote and be voted for at an election to a local government council.

(5) The functions to be conferred by Law upon local government councils shall include those set out in the Fourth Schedule to this Constitution.

(6) Subject to the provisions of this Constitution-

(a) The National Assembly shall make provisions for statutory allocation of public revenue to local government councils in the Federation; and

(b) The House of Assembly of a State shall make provisions for statutory allocation of public revenue to local government councils within the State. 
than the first term of office of some of these Governors. This, to say the least, is very unfortunate.

It is also clear from the provision of section 7(6) that the Local Government is to be funded from revenues from both the Federation Account and the State Account. If this provision were to be implemented candidly, an average Local Government Council in Nigeria should be very buoyant. But is that true of the Local Government Councils of Nigeria? The question must be answered in the negative. For, as noted by Teniola, in his essay earlier referred to,$^{21}$ there is hardly any Local Government in Nigeria that can carry out any development project. What then is the reason?

This will lead us to the question of autonomy. What is at issue here is financial autonomy or independence. There is no doubt that politically, the Local Government Councils can be said to be fairly autonomous, even though the State Governments are withdrawing the relative autonomy granted to them by the Constitution through the inauguration of Caretaker Committees. Regarding financial autonomy, however, it does appear that the Constitution itself is not helping matters. The provision of the Constitution that seems to be creating problems for the Local Governments is section 162(5)-(8). ${ }^{22}$

Whatever the system of Local Government may have gained through the insertion of section 7(1) into the Constitution or through the implementation of the Dasuki reform proposals of 1976 has wholly

21 ibid.

22 Section 162(5) -(8) of the 1999 Constitution of the Federal Republic of Nigeria is reproduced here for emphasis:

(5) The amount standing to the credit of Local Government Councils in the Federation Account shall also be allocated to the State for the benefit of their Local Government Councils on such terms and in such manner as may be prescribed by the National Assembly.

(6) Each State shall maintain a special account to be called 'Stated Joint Local Government Account' into which shall be paid all allocations to the Local Government Councils of the State from the Federation Account and from the Government of the State.

(7) Each State shall pay to Local Government Councils in its area of jurisdiction such proportion of its total revenue on such terms and in such manner as may be prescribed by the National Assembly.

(8) The amount standing to be credit of Local Government Councils of a State shall be distributed among the Local Government Councils of that State on such terms and in such manner as may be prescribed by the House of Assembly of the State. 
been taken away by the provisions of section 162 of the 1999 Constitution. In other words, whereas political autonomy is guaranteed by section $7(1)$, section 162 has rendered the local government administration completely prostrate.

Indeed, those who mooted the idea of 'State Joint Local Government Account' mentioned in subsection (6) of section 162 might have meant well, but the unfolding events have since shown that they misread the political pulse of Nigerian politicians. The idea could have arisen from an interpretation of section 7(6) pursuant to which Local Governments are to be funded by public revenues accruing from both the Federation Account and the State Account. Accordingly, the joint account is expected to be funded by both the Federal Government and the State Government for the benefit of the Local Governments. Which is even the reason why subsection (7) of section 162 stipulates that 'each State shall pay to Local Government Councils in its area of jurisdiction such proportion of its total revenue on such terms and in such manner as may be prescribed by the National Assembly'.

That is the rule, and, indeed, the basis of the State Joint Local Government Account. But what is the reality on the ground? This provision has been grossly abused by State Governors to deprive the Local Government Councils of their own share of statutory allocation. Not only do the States fail to fund the Local Governments, as mandated by the Constitution, ${ }^{23}$ there are allegations across the country that funds meant for the Councils from the Federation Account are often diverted or hijacked by the State Governments. The result is that whenever a Local Government Chairman (executive or caretaker) needs to spend money, he goes cap in hand to 'His Excellency', the State Governor, for approval. This is the scenario that has been playing itself out since the return of the country to democratic rule in May 1999.

\section{EVALUATION AND CONCLUDING REMARKS}

\section{Evaluation}

About four years ago (October 2012), the National President of the Nigerian Union of Local Government Employees, Comrade Ibrahim

231999 Constitution, ss 7(6) and 162(7) 
Khaleel, at a workshop organized by the Centre for Democracy and Development, ${ }^{24}$ had observed thus:

It is sad to note that with the level of corrosive abuses and serial violation on the security of local government system by the Third Republic politicians in Nigeria, [the] local government is fast sliding back into the events after the military takeover of 1996 and before the creation of States.

The main cause of what this unionist called 'corrosive abuses' is the lack of financial autonomy at this tier of government. There is no doubt that the framers of the 1999 Constitution must have realized by now that the creation of the so-called 'State Joint Local Government Account' was an error. If the Local Governments cannot access their own share of the revenue of the Federation directly, then their existence is at best otiose. The irony of this is that the same Constitution that renders the Local Government Councils powerless has also saddled them with enormous responsibilities, such as, the economic development of the State in so far as the areas of authority of the Councils are affected, collection of rates, radio and television licences, construction and maintenance of roads, streets, street lightings, drains and other public highways, etc. ${ }^{25}$ The point is that if the Local Governments cannot access the funds allocated to them from the Federation Account directly they cannot possibly discharge these functions efficiently.

\section{The Way Forward}

What then is the way forward in the perennial search for local government autonomy in Nigeria? The first step is to acknowledge that there was an error in the drafting of section 162 of the 1999 Constitution in so far as the funding of Local Governments is concerned. The error should be corrected as a matter of urgency. This can be done through the current effort by the National Assembly to review the 1999 Constitution. If Local Governments are to be treated as the third tier of government under our tripartite governmental arrangement, then they must be able to access the funds allocated to them from the

24 Eric Teniola (n 2).

25 Fourth Schedule to the 1999 Constitution, for a full list of the functions of a Local Government Council. 
Federation Account directly, in the same way as the State Governments receive their own allocations without going through any intermediary. It has been argued that the joint account is designed to ensure financial probity on the part of the Local Governments. This argument does not hold water as it merely creates the impression that the State Governments themselves are saints. There are laid-down procedures for the monitoring of public finance at every level of government. One of them is the control exercised by the Legislature over public funds. It is suggested that the parliamentary watchdog role played by both the National Assembly and the House of Assembly of each State over public finance be extended to the funds allocated to the Local Governments from the Federation Account and the State Account, respectively. Any Local Government functionary caught embezzling or misappropriating public funds should be prosecuted in the court of law.

Second, the Local Government Legislative Council should be strengthened so that elected Councillors who make up this Council can properly play their role as the watchdog of the people at the grassroots level. This will enhance the operation of the doctrine of checks and balances, thereby checking the excesses of Local Government Chairmen a good number of whom are known to have constituted themselves into local overlords.

Third, the idea of local government caretaker committee should be completely jettisoned and outlawed through a constitutional amendment that makes it mandatory for a sitting Governor to conduct election at this tier of government not later than thirty (30) days to the expiration of the tenure of the administration of a given local government. Besides, and in order to prevent the State Governors from imposing their puppets on the Councils, elections into the 774 Local Government Councils in Nigeria should henceforth be conducted by the Independent National Electoral Commission (INEC). The idea is that if funds meant for local governments are allocated directly to them from the centre, as being herein proposed, it is logical that the federal government should, through the relevant statutory agencies (like INEC), be able to play an oversight role in the affairs of this tier of government, including the election of Council Chairmen and Councillors.

Fourth, there should be a uniform tenure of office for all the 774 Local Governments in Nigeria. The present practice where some States operate two years and others three years is not healthy. It should be clearly stated in the Constitution that the elected Chairmen and Councillors shall be in office for four years and that they can be re- 
elected for another term of four years, and no more. The stability or certainty of tenure will deliver the Councils from the capricious control of State Governors who now treat these Councils as annexes of the State Government Houses.

\section{CONCLUSION}

The local government is, without any doubt, the closest tier of government to the masses. It is the political platform through which the dividends of democracy can be delivered to the grassroots population. Accordingly, if the system of local government administration in Nigeria fails then the entire machinery of government becomes ineffectual. It is often said that democracy is the government of the people by the people and for the people. The most visible means by which the electorate, the majority of whom reside in the rural areas, can feel the impact of government is through an efficient local government administration, one that is able to provide basic amenities like roads, markets, potable water, etc., for them. It is for this reason that the reform of the local government, premised largely on the foregoing blueprint, becomes imperative. It is even much more so now that the recession in the country's economy has compelled the government of President Muhammadu Buhari to pursue economic diversification, with a focus on agriculture. And as the golden era of agriculture being the mainstay of the economy is being gradually brought back, needless to say that in the pursuit of the diversification agenda, an efficient local government system is expected to play a bourgeoning role. 